\title{
THE IMPORTANCE OF WORK CULTURE ON JOB SATISFACTION AND GOOD GOVERNANCE IN THE TRANSPORTATION INDUSTRY
}

\author{
Azman Hashim International Business School \\ University of Technology Malaysia (UTM) \\ Malaysia \\ aabdulkahar2@graduate.utm.my \\ and \\ Business School \\ University of Education, Winneba \\ Ghana \\ aka11@live.co.uk, akadam@uew.edu.gh
}

Abdul-Kahar Adam*

Nasser Salim Al Saadi

Azman Hashim International Business School

University of Technology Malaysia (UTM)

Malaysia

nasseralsaadi2020@hotmail.com

\section{Dr. Ebi Shahrin Bin Suleiman}

Azman Hashim International Business School

University of Technology Malaysia (UTM)

Malaysia

m-shahrin@utm.my

*Corrosponding author's Email: aabdulkahar2@graduate.utm.my

Peer-review under responsibility of 4th Asia International Multidisciplinary Conference 2020 Scientific Committee http://connectingasia.org/scientific-committee/

(C) 2020 Published by Readers Insight Publisher, lat 306 Savoy Residencia, Block 3 F11/1,44000 Islamabad. Pakistan,

editor@ readersinsight.net

This is an open access article under the CC BY-NC-ND license (http://creativecommons.org/licenses/by-nc-nd/4.0/). 


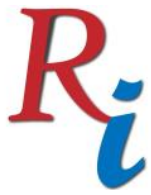

\section{Asia Proceedings of Social Sciences (APSS) \\ www.readersinsight.net/APSS}

\section{A b s t r a c t}

This is theoretically basic research with conceptual studies theories to establish the importance of work culture in an organisation. Work Culture is seen as the behaviours, attitudes, commitments and staff performance are key in advancing towards orgnisational objectives. Work Culture have direct correlation with job satisfaction and good governance and that is if organisations really want to grow their business. Job satisfaction on the other hand states that both extrinsic and intrinsic factors such as the salary increment and employees' welfare are paramount to the hearts of staff. Moreover, good governance demands that the following principles must be put into practice namely accountability, integrity, compliance, trustworthy, discipline, ethical leadership, efficiency and effectiveness, and participation. In the methodology, a random sample of 40 public bus drivers were interviewed with their responses used to generate data for analysis in SmartPLS. The results indicated that all the three (3) variable constructs are valid and reliable. The Cronbach Alpha for Job Satisfaction, Good Governance, and Work Culture was 0.7, 0.8, and 0.7 consecutively. According to Hair et al., (2007) argued that a Cronbach alpha value of 0.6 and above means there is high reliability. This was a quantitative research study. This conceptual research showed that in the transport industry especially the public sector more attention must be paid to these three variables in order to achieve objectives namely good governance, job satisfaction and work culture to improve the human resource management practices in the public transportation industry.

\section{Rese a r ch H igh I ight s}

Highlight 1 The direct effect is positively reflective

Highlight 2 The Indirect Effects are also positively reflective correlated

Highlight 2 The model is a complete mediation since the total effect is zero or near zero. 


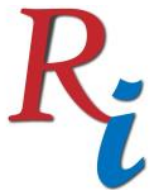

\section{Asia Proceedings of Social Sciences}

(APSS)

www.readersinsight.net/APSS

\section{Graphical A bstract}

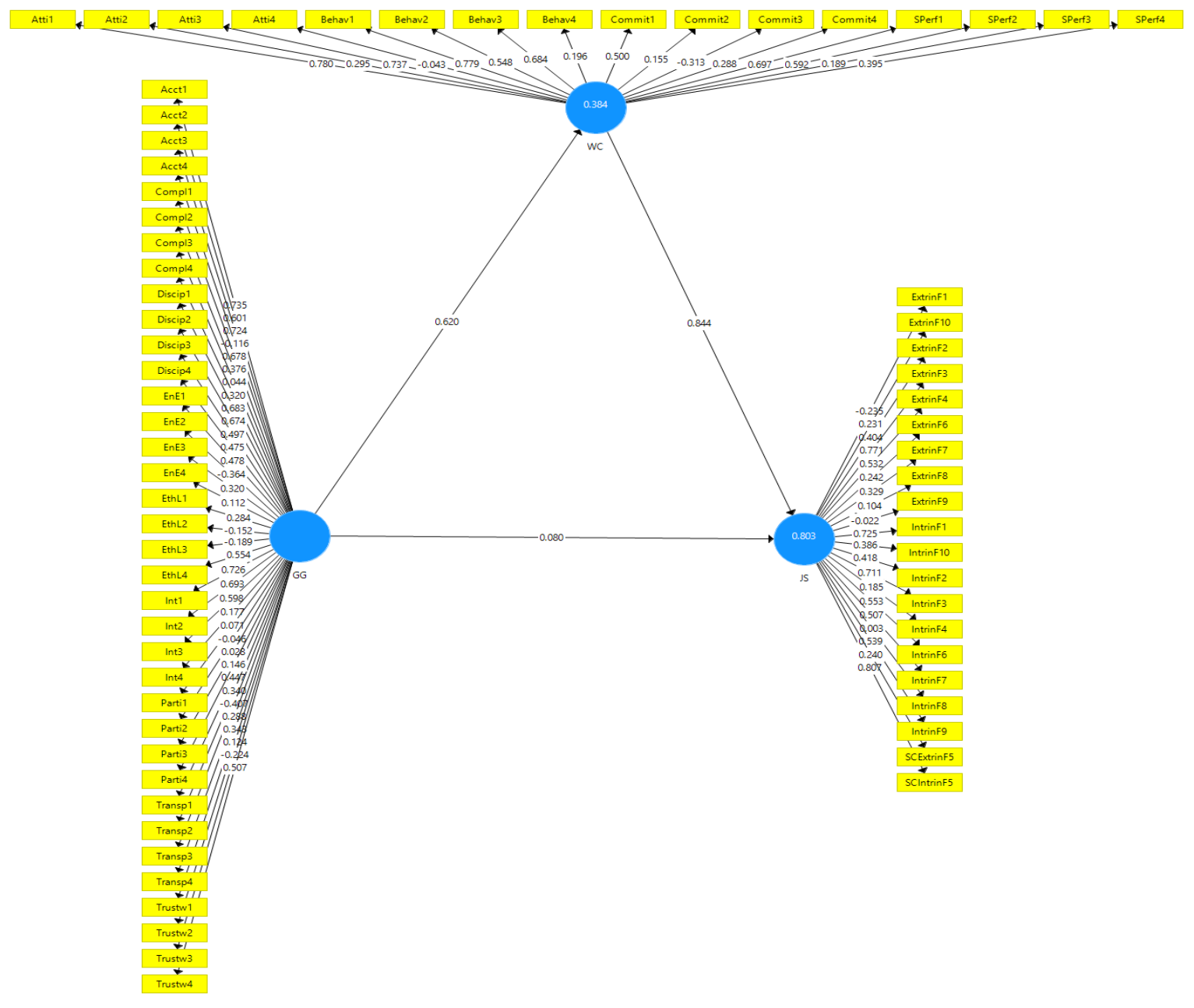

\section{Research Objectives}

\section{Research Questions}

1. Is there any theoretical relationships or correlations among these three (3) variables namely Job Satisfaction, Good Governance and Work Culture?

2. What are the importance of adopting good governance, work culture, and job satisfaction to public sector organisations?

\section{Objective}

1. To find the relationships or correlations among Job Satisfaction, Good Governance and Work Culture

2. To establish the importance of the adoption of job satisfaction, good governance, and work culture 


\section{Methodology}

This is a basic research; hence a quantitative approach is adapted in this study as the research designed. The target respondents for this study was public bus drivers and forty (40) of them were selected at a random. The 40 respondents represent a qualified number to run in SmartPLS 3 for analysis. A questionnaire as an instrument was developed with constructs were administered in a survey format to these respondents for data capturing and analysis.

\section{Results}

Below are the path models and the Cronbach Alpha in determining the construct validity and reliability of the instruments.

\section{Construct Reliability and Validity}

\begin{tabular}{|c|c|c|c|c|c|c|c|}
\hline Matrix & 擗章 & Cronbach's Alpha & 掉真 rho_A & 掉章 & Composite Reliab & ility & 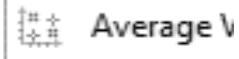 \\
\hline & & Cronbach's Al... & & 10_A & Composite Rel... & Ave & erage Varian... \\
\hline GG & & 0.815 & & 873 & 0.793 & & 0.191 \\
\hline JS & & 0.728 & & 845 & 0.778 & & 0.214 \\
\hline WC & & 0.711 & & 851 & 0.780 & & 0.259 \\
\hline
\end{tabular}

Figure 3. Proof of Test Run in SmartPLS 3 Bootstrap

Table 1. Construct Validity and Reliability

\begin{tabular}{lll}
\hline Variables & Number of Items & Cronbach Alpha \\
\hline Job Satisfaction (DV) & 20 & 0.728 \\
Good Governance (IV) & 36 & 0.815 \\
Work Culture (Mediator V) & 16 & 0.711 \\
\hline
\end{tabular}

\section{Reliability Test}

This was for the purpose of testing for internal consistency of the instruments designed. SmartPLS was used to generate this reliability analysis following the data derived under Cronbach Alpha coefficients. According to Hair et al., (2007) argued that a Cronbach alpha value of 0.6 and above means there is high reliability but below this value may be revised as appropriate. As the above table 1 showed that all the constructs to the various variables have very high reliability of more than 0.6 . This indicates that the process and constructs adopted at this stage is more reliable and valid for this study. 


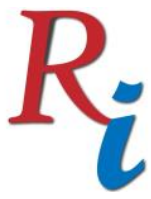

\section{Asia Proceedings of Social Sciences (APSS) \\ www.readersinsight.net/APSS}

\section{Findings}

The above figure 4 shows that Work Culture (WC) completely mediates Good Governance (GG) and Job Satisfaction (JS) because the indirect effects are highly correlated and positively reflective and since the direct effects also representing the total effect is almost zero means there is complete mediation and it has satisfied the for stages in establishing mediation (Barron and Kenny (1986); James and Brett (1984); Judd and Kenny (1981)). In this study all the constructs are important to the objectives of the study hence there is no need for constructs to be deleted because of low outer loadings.

\section{References}

Baron, R.M., and Kenny, D.A., (1986), The Moderator-Mediator Variable Distinction in Social Psychological Research: Conceptual, Strategic, and Statistical Considerations, Journal of Personality and Social Psychology, Vol. 51, No. 6, pp. 1173-1182

Hair, J., Money, A., Samouel, P. and Page, M. (2007), "Research Methods for Business", Education + Training, Vol. 49 No. 4, pp. 336-337. https://doi.org/10.1108/et.2007.49.4.336.2

James, L. R., \& Brett, J. M. (1984). Mediators, moderators, and tests for mediation. Journal of Applied Psychology, Vol. 69, No. 2, pp. 307-321. https://doi.org/10.1037/0021$\underline{9010.69 .2 .307}$

Judd, C. M., \& Kenny, D. A. (1981). Process analysis: Estimating mediation in treatment evaluations. Evaluation Review, Vol. 5, No. 5, pp. 602-619. https://doi.org/10.1177/0193841X8100500502

Author's Biography

Dr. Ebi Shahrin Bin Suleiman is a Senior Lecturer at the Universiti Teknologi Malaysia, UTM in the Azman Hashim International Business School. He supervises a lot of PhD candidates in the faculty.

Nasser Salim Al Saadi is a PhD candidate at the Universiti Teknologi Malaysia, in the Azman Hashim International Business School, formerly called Faculty of Management.

Abdul-Kahar Adam is a PhD candidate at the Universiti Teknologi Malaysia, in the Azman Hashim International Business School, formerly called Faculty of Management. Abdul-Kahar is also a Lecturer in Ghana at the University of Education, Winneba, Ghana. 